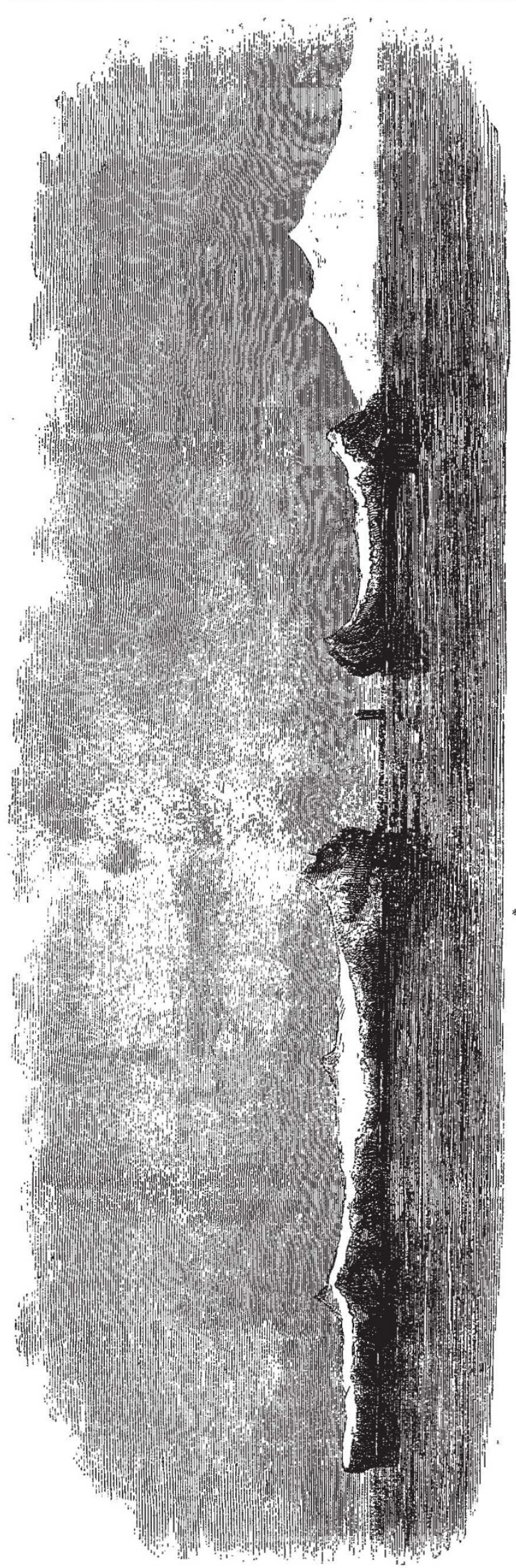

\title{
POSSESSION ISLANDS
}

SEE.ING is believing. The fitness of Possession Islands for the residence of an observing party during a whole year may be best judged from the accompanying illustration, which is accurately copied from a sketch made by Dr. Hooker at the time a landing was effected. (See NATURE, vol. vii. p. 384.) This was in midsummer, and with an exceptionally calm sea. The spot where the crew landed is indicated by an * underneath. A sketch of the place by Captain Davis is given at the beginning of chapter vii. in the first volume of Ross's Voyage.

\section{ON THE ORIGIN AND METAMORPHOSES OF INSECTS*}

II.

I $N$ the Coleoptera, the larvæ differ very much in form. 1 The majority are elongated, active, hexapod, and more or less depressed; but those ot the Weevils (Pl. 2, Fig 6), of Scolytus, (P1. 2, Fig. 4), \&c., which are vegetable feeders, and live surrounded by their food, as, for instance, in grain, nuts, \&c., are apod, white, fleshy grubs, not unlike those of bees and ants. The larvæ of the Longicorns, which live inside trees, are long, soft, and fleshy, with six short legs. The Geodephaga, corresponding with the Linnean genera Cicindela and Carabus, have six-legged, slender, carnivorous larvæ; those of Cicindela. which waylay their prey, being less active than the hunting larvæ of the Carabidæ. The Hydradephaga, or water-beetles (Dyıicidæ and Gyrinidæ) have long and narro: larvæ (Pl. 4, Ftg. 6), with strong sickle-shaped jaws, short antennæ, four palpi, and six small eyes on each si le of the head; they are very voracious. The larvæ of the Staphylinidæ are by no means unlike the perfect insect, and are fuund in similar situations; their jaws are powerful, and their legs moderately strong. The larva of the Lamellicorn beetles (cockchafers, stag-beetics, \&c.) feed einer on vegetable or on dead animal matter. They are long, soft, flesny, grubs, with the abdomen somewhat curved, and generally lie on their side. The larvæ of the Elateridæ, known as wireworms, are long and slender, with short legs. Those of the glowworm are not unlike the apterous femile. The male glowworm, on the contrary, is very different. It has long, thin, brown wing-cases, and often fles into rooms at night, attracted by the light, which it probably mistakes for its mate.

The metamorphoses of the Cantharidæ are very remarkable, and will be described subsequently. The larvæ are active and hexapod. The Phytophaga (Crioceris, Galeruca, Haltica, Chrysomea, \&c.) are vegetable feeders, both as larvæ and in the perfect state. The larvæ are furnished with legs, and are not unlike the caterpillars of certain Lepidoptera.

The larva of Coccınella (the Ladybird) is somewhat depressed, of an elongated ovate form, with a small head, and moderately strong legs. It feeds on Aphides.

Thus, then, we see that there are among the Coleoptera many different forms of larvæ. Macleay considered that there were five principal types.

I. Carnivorous hexapod larvæ, with an elongated, more or less flattened body, six eyes on each side of the head, and sharp falciform mandibles (Carabus, Dyticus, \&c.).

2. Herbivorous hexapod larvæ, with a fleshy, cylindrical body, somewhat curved, so that the animal lies on its side (Lucanus, Melolontha).

3. Apod grub-like larvæ, with scarcely the rudiments of antennæ (Curculio).

4. Hexapod antenniferous larvæ, with a subovate body, the second segment being somewhat larger than the others (Chrysomela, Coccinella). 
5. Hexapod antenniferous larvæ, of oblong form, somewhat resembling the former, but with caudal appendages (Meloe, Sitaris).

The pupa of the Coleoptera is quiescent, and * "the parts of the future beetle are plainly perceivable, being incased in distinct sheaths; the head is applied against the breast ; the antennæ lie along the sides of the thorax ; the elytra and wings are short and folded at the sides of the body, meetıng on the under side of the abdomen; the two anterior pairs of legs are entirely exposed, but the hind pair are covered by wing-cases, the extremity of the thigh only appearing beyond the sides of the body."

In the next three orders, the Orthoptera (grasshoppers, locusts, crickets, walking-stick insects, cockroaches, \&c.), Euplexoptera (earwigs), and Thysanoptera, a small group of insects well known to gardeners under the name of Thrips, the larvæ when they quit the egg ( $\mathrm{Pl}$. I and 2, Figs. I and 2) already much resemble the mature form, differing in fact principally in the absence of wings. which are more or less gradually acquired, as the insect increases in size. They are active throughout life. Those specimens which have rudimentary wings are, however, usually called pupæe.

The Neuroptera present, perhap 3 , more differences in the character of their metamorphoses than any other order of insects. The larvæ are generally active, hexapod, little creatures, and do not differ in appearance so much as those, for instance, or the Coleoptera, but the essential difference is in the pupæ; some group -, as, for instance, the Psocidæ, Termitidæ, Libellulidæ, Ephemeridæ, and Perlidæ, remaining active throughout life, like the Orthoptera ; while a second division, including the Myrmeleonida, Hemerobiidæ, Sialıdæ, Panorpidæ, Raphididæ, and Mantispidæ, have quiescent pupæ, which, however, in some cases, acquire more or less power of locomotion shortly before thry assume the mature state; thus, the pupa of Raphidia, though motionless at first, at length acquires strength enough to walk, while still enclosed in the pupa skin, which is very thin.t

One of the most remarkable families belonging to this order is that of the Termites, or white ants. They abound in the tropics, where they are a perfect pest, and a serious impediment to human development. Their colonies ar-extremely numerous, and they attack woodwork and furniture of all kinds, generally working from within, so that their presence is often unsuspecied, until it is suddenly found that they have completely eaten away the interior of some post or table, leaving nothing but a trin outer shell. Their nests, which are made of earth, are sometimes ten or twelve feet high, and s'rong enough to bear a man. One species, Termes lucifugus, is found in the South of France, where it has been carcfully studied by Latreille. He found in these communities five kinds of individuals - (I) males; (2) females, which grow to a very large size, their bodies being aistended with eggs, of which they sometimes lay as many as 80,000 in a day; (3) a kind described by some observers as Pupæ, but by others as neuters. These differ very much from the rest, having a long, soft body without wings, but with an immense head, and very large, strong jaws. These individuals act as soldiers, doing apparently no work, but keeping watch over the nest and attacking intruders with great boldness. (4) Apterous, eyeless individuals, somewhat resembling the winged ones, but with a larger and more rounded head; these constitute the greater part of the community, and like the workers of ants and bees, perform all the labour, building the riest and collecting food. (5) Latreille mentions another kind of individual which he regards as the pupa, and which resembles the workers, but has four white tubercles on the back, where the wings will afterwards make their appesrance Thele is still, however, much difference of opinion among entomologists, with

* Westwood's Introduction, vo!. i. p. $3^{6}$.

† Ibid, vol, ii. p. 52. reference to the true nature of these different classes of individuals. M. Lespés, moreover, who has recently studied the same species, describes a second kind of male and a second kind of female. The subject, indeed, is one which offers a most promising field for future study.

Another interesting family of Neuroptera is that of the Ephemeræ, or mavflies (Pl. 3, Fig. I), so well known to fi-hermen. The lirvæ (Pl. 4, Fig. I) are semi-transparent, active, six-legged little creatures, which live in water, and having at first no gills, respire through the general surface of the body. They grow rapidly and change their
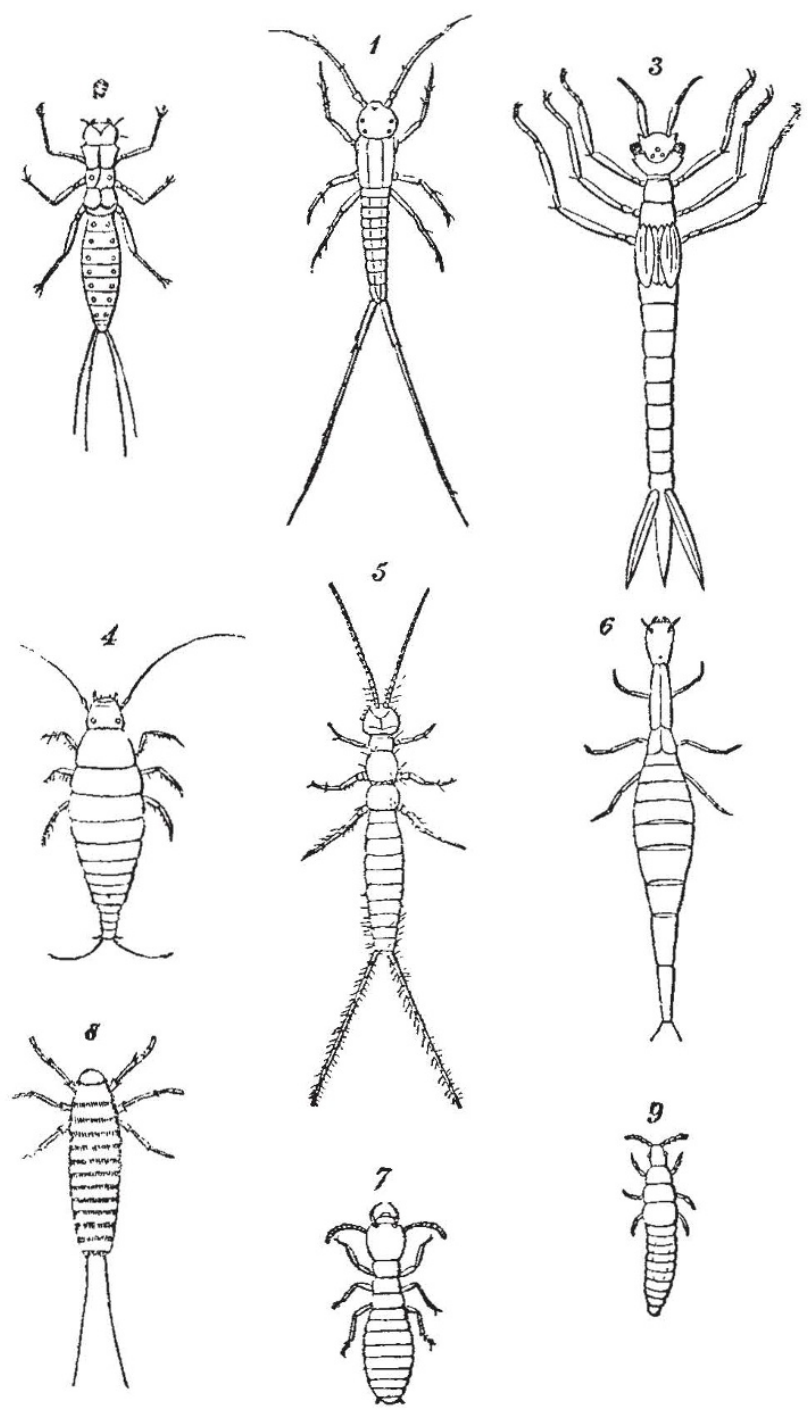

Plate 4

PL. 4. - FIG. I, Larva of Chloeon. 2, Larva of Meloe (a ter Chapuis Candeze) 3, I arva of Ca epteryx (afier Loon Dutour). 4, Larva of Sitaris of Termes (after Blancharu). 8, Larva of Siylops. 9, Larva of Thrips.

skin every few days. After one or two moults they acquire seven pairs of branchiæ, or gills, which are in the form of leaves, one pair to a segmt nt. When thev are about half ; rown, the posterior angles of the tuo posterior thoracic seyments begin to elonyate. These elongations become more and more marked with evt ry skin. One morning, in the month of June, some years ago, I observed a full-grown larva, which had a glistening appearance, owing to the pre- 
sence of a film of air under the skin. I put it under the microscope, and then, having added a drop of water with a pipette I put the instrument down and looked through the glass. To my astonishment, the insect was gone, and an empty shin only remained. I then caught a second spec1men, in a similar condition, and put it under the microscope, hoping to see it come out. Nor was I disappointed. Veiy few moments had elapsed, when I had the satisfaction of seeing the thorax open along the middle of the back; the two sides : urned over; the instct literally walked out of itself, unfolded its wings, and in an instant flew up to the window. Several times since, I have had the pltasure of witnessing this wonderful change, and it is really extraordinary how rapidly it takes place; from the moment when the skin first cracks, not ten seconds are over before the insect has flown away.

The Dragon-flies, or Horse-stingers, as they are sometimes called, from a mistaken idea that they sting severely enough to hurt a horse, though in fact they are quite harmless, also spend their early days in the water. The larve are brown, sluggish, ugly creatures, with six legs. They feed on small water animals, for which they wait very patiently, either at the bottom of the water or on some water plant. The lower jaws are attached to a long folding rod, and when any unwary little wretch approaches too near the larva, this apparatus is shot out with great velocity, and the prey which comes within its reach seldom escapes. In their perfect condition, also, Dragonflies feed on other insects, and may often be seen hawking round ponds. The so-called Ant-lion in many respects resembles the Dragon-flies, but the habits of the larvæare very dissimilar. They do not live in the water, but prefer dry places, where they bury themselves in the loose sand, and seize any little insect which passes, with their long jaws. The true Ant-lion makes itself a little pit in loose ground or sand, and buries itself at the bottom. Any inattentive little insect which steps over the edge of this pit immediately falls to the bottom, and is instantaneously seized by the Ant-lion. Should the insect escape and attempt to ciimb up the side of the pit, the Ant-lion is said to throw sand at $\mathrm{i}$, knocking it down again.

One other family of Neuroptera I must mention, the Hemerobiidæ. The perfect insect is a beautiful, lacewinged, very delicate, green insect, something like a tender Dragonfly, and with bright green, very touching eyes. The females deposit their eggs on plants, not directly on the plant itself, but attached to it by a long white slender footstalk. The larvæ have six legs and powerful jas's, and make themselves very useful in destroying the Hopfly.

The insects forming the order Trichoptera are well known in their larval contition, under the name of caddis worms. These larve are not altngether unlike caterpillars in form, but they live in water - which is the case with very few lepidopterous laria-and form for th $\mathrm{mselves}$ cylmdrical cases or tubes, built up of sand, little stone-, bits of stick, leaves, or even shells. They generally feed on vegetable substances, but will also attack minute freshwater anımals. When full grown, the larva fastens its case to a stone, the stem of a plant, or some other fixed substance, and closes the two $t$ nds with an open grating of silken threads, so as to admit the free access of water, while excluding enemies. It then turns into a pupa, which bears some rescmblance to the perfect insect, "except that the antennæ, palpi, wings and legs are shorter, enclosed in separate sheaths and arranged upon the breast." The pupa remains quet in the tube until nearly ready to emerge, when it comes to the surface, and in some cases creeps out of the water. It is not therefore so complttely motionless as the pupa of Lepidoptera.

The Diptera, or Flies, comprise insects with two wings only, the hinder pair being represented by minute clubshaped organs called halteres. Flies quit the egg generally in the form of fat, fleshy, legless grubs. They feed principally on decaying animal or vegetable matter, and are no doubt useful as scavengers. When full grown they turn into pupæ which are generally inactive; those of some gnats, however, swim about. Other species, as the gadflies, deposit their eggs on the bodies of animils, within which the grubs, when hatched, feed. The mouth is generally furnished with two hooks which serve instead of jaws. The pupæ are of two kinds. In the true flies, the outer skin of the full-grown larva is not shed, but contracts and hardens, thus assuming the appearance of an oval brownish shell or case, within which the insect changes into a chrysalis. The pupæ of the gnats, on the contrary, have the limbs distinct and enclosed in sheaths. They are generally inactive, but some of the aquatic species continue to swim about.

One group of Flies, which is parasitic on horses, sheep, bats, and other animals, has been called the Pupipara, because it was supposed that they were not born until they had arrived at the condition of pupæ. They come into the world in the form of smooth ovate bodies, much resembling ordinary dipterous pupæ, but as Leuckart has shown, they are true, though abnormal, larvæ.

The next order, that of the Aphaniptera, is very small in number containing only the different species of Flea. The larva is long, cylindrical, and legless; the chrysalis is motionless, and the perfect insect is too well known, at least as regards its habits, to need any description.

Unlike the preceding orders of insects, the Heteroptera quit the egg in a form, differing from that of the perfect insect principally in the absence of wings. The species constituting this group, though very numerous, are generally small, and not so familiarly known to us as those of the other large orders, with indeed one exception, the wellknown Bug. This was not, apparently, an indigenous insect, but seems to have been introduced. Shakespeare uses the word several times, but always in the sense of a bugbear, and not with reference to this insect. In this country it never acquires wings, but is stated to do so sometimes in warmer countries. The Heteroptera cannot exaculy be said either to sting or bite. The jaws, of which, as usual among insects, there are two pairs, are like needles, which are driven into the flesh, and the blood is then sucked up the lower lip, which has the form of a tube. This peculiar structure of the mouth prevails throughout the whole order; consequently their nutriment consists almost entirely of the juices of animals or plants. In their metamorphoses the Heteroptera resemble the Orthoptera; they are active through life, and the young resemb!e the perfect insects except in the absence of wings, which are gradually acquired. The majority are dull in colour, though sume few are very beautiful. The Homoptera agree with the Heteroptera in the structure of the mouth, and in the metamorphoses. They differ principally in the front wings, which in Homoptera are membranous throughout, while in the Heteroptera the front part is thick. As in the Heteroptera, however, so also in the Homoptera, some species do not acquire wings. The Cicada, so celebrated for its song, and the lanthorn fyy, belong to this group. So also does the so-called Cuckoospit, so common in our gardens, which has the curious faculty of secreting round itself a quantity of frothy matter which serves to protect it from its enemies. But the best known insects of this group are the Aphides, or Plant-lice; while the most useful belong to the Coccidæ, or scale insects, from one species of which we obtain the substance called lac, so extensively used in the manufacture of sealingwax and varnish. Several species also have been used in dyeing, especially the Cochineal insect if Mexıco, a species which lives on the Cactus. The male Coccus is a minute, active insect, with four comparatively large wings, while the female, on the contrary, never acquires wings,

* Die Fortpflanzung und Entwickelung der Pupiparen. Von Dr. R. Leuckart. (Halle, 2848 .) 
but is very sluggish, broad, more or less flattened, and, in fact, when full grown, looks like a small brown scale.

The larva of Lepidoptera are familiar to us all, under the name of caterpillars. The insects of this order in their larval condilion are almost all phytophagous, and are very uniform both in structure and habits. The body is long and cylindrical, consisting of thirteen segments; the head is armed with powerful jaws; the three following segments, the future prothorax, mesothorax, and metathorax, bear three pairs of simple articulated legs. Of the posterior segments, five also bear false or pro-legs, which are short, unjointed, and provided with a number of hooklets. A caterpillar leads a dull and uneventful life; it eats ravenously, and grows rapidly, casting its skin several times during the process, which generally lasts only a few weeks, though in some cases, as for instance the goat-moth, it extends over a period of two or three years, after which the larva changes into a quiescent pupa or chrysalis.

( $T$ o be continued.) JOHN LUBBOCK

\section{ON THE STRUCTURE OF STRIPED MUS- CULAR FIBRE}

A HIGHLY interesting paper on the above subject was read before the Royal Society on A oril 3, by Mr. E. A. Schäfer, of University College. The muscle of the limbs of the large water-beetle formed the subject of the investigation, and it was examined immediately after removal from the living animal, without the addition of any reagent, to prevent the introduction of complications. According to the author, a muscular fibre consists of a homogeneous ground substance, which appears at first sight to be formed of two distinct substinces, one dim and the other bright, arranged in alternate discs at right angles to the direction of the fibre; and a vast number of minute rod-like bodies, imbedded in the protoplasmic basis, having their axes coincident with that of the fibre itself. These are termed muscle rods; in the muscle at absolute rest they are uniformly cylindrical, and produce the appearance of a simple longitudinal fibrillation in the fibre, with no transverse striping. But when in action these muscle-rods are terminated at each extremity by a knob, and are consequently dumb-bell shaped. It is the ze kn bs which give the appearance of the line of dots which is always described as existing in the middle of each bright transverse band of the muscle fibre, whereas the dim one is that in which the shafts of the muscle-rods are imbedded. In contraction of the muscle, the heads of the rods become enlarged at the expense of the shafts, the extremities of each muscle-rod consequently approaching one another; and the enlarged heads come nearer to their neighbours of the same series, and to those of the next series which meet them in the bright stripe, the line of dots now appearing as a dark transverse band with bright borders. As contraction proceeds the shaft of the muscle-rod tends to, and ultimately disappears, leaving an appearance of alternate dark and light stripes; the former however are in this case due to the enlarged juxtaposed extremities of the rods, the latter on the other hand being mainly due to the accumulation of the ground-substance in the intervals between their shafts. An examination of minute oil-globules imbedded in gelatine shows cleariy that they give the appearance under the microscope of dark spots with a brilliant surrounding, and several side by side produce the effect of a bright band. From many considerations it can be shown that the bright transverse bands in muscle are similarly produced by the juxıaposition of the rod-heads, among which are the following:- $\mathbf{I}$. When the rodheads are smaller the bright bands are narrower. 2. When the rod-heads have become merged with the shafts in full contraction, the bright transverse stripes entirely dis. appear. 3. When in contraction the rod-heads enlarge and encroach on the shaft, their bright borders accompany them and encroach on the dim substance, so that at last all appearance of dimness becomes entirely obliterated, the bright borders becoming blended in the middle. 4. The part of the muscle-rod where the head joins the shaft, is rendered indistinct by the brightness around the rod-head; whereas if this brightness were inherent in the ground substance, this part of the rod would stand out all the darker by the contrast. 5. The appearance of a transverse section is corroborated; for in this case the rod-heads are seen so close together that the optical effect of any one would become merged into those of its neighbours: consequently the whole of the intermediate substance would appear bright; and this is actually found to be the case. 6 . The fact that both the dim and the bright substance of resting muscle appear doubly refracting, would indicate that they are of the same nature.

Mr. Schäfer with polarised light has found that all the ground-substance of the fibre is doubly refractive, the rods alone being singly refractive. $\mathrm{He}$ concludes the paper by offering a conjecture as to the mode of muscular conrraction, in which he is inclined to regard the groundsubstance as the true contractile part, and the rods as elastic structures, merely serving to restore the fibre to its original length.

\section{NOTES}

A RUMDUR as to the fate of Sir Samuel and Lady Baker, of a kind similar to thsie which have ever and anon filled the air with reference to the andying $\mathrm{L}$ :vingstone, appeared in the Times of Thursday last. At the end of last year, with his force dwindled down to 200 men, Sir Samuel had penetrated soath until he had reached the territory of the chief of th: tribes squatting near the great $1 \mathrm{k}$ ss, wh, had hitherto ben friendly to the Egyptian governnent. His reseption of Baker and his companions was however the reverse of friendly. Whatever the cause, a desperate confiict with the natives ensued. and after much hard fighting, Baker was compelled to retreat with but 30 out of his 200 men. It was with the utmost difficulty that the survivors succeeded in intrenching themselv $-\mathrm{s}$ in a s: $\mathrm{n}$ ll fort, whence to beat back further attacks. Such, accord ng to report, was the state of matters at the end of last yeur. Tne present rumour is that Sir Samuel and Lady Baker having at last been compelled to surrender, were immediately afterwards murdere.1. A telegram from H.M. Consul at Alexandria, dated the afternoon of last Thursday, announces that no intelligence of any sort respecting Sir Samuel and Lady Bxker had been received by the Egyptian Government, or by any other, since March 5 last. A teleyiam of April 19, from the Alexandria Daily Neres Correspondent states that the rumour seems to be utterly unfounded. We have, moreover, been assured by one who has the best opportunities of knowing, that no news has really been received, and that the reports about Sir Samuel are inventions: "there is not," he writes us, "a word of truth in them."

WE regret to announce that Baron Liebig's illness, to which we referred last week, has terminated in death. The great chemist died on the I8th instant, aged nearly 70 years, having been born at Darmstadt on May 12, 1803. His funeral took place with great ceremony at Munich on the 2 rst. We hope, in an early number, to be able to give a memoir of the late Baron.

IT is with the greatest regret that we announce the death, on the 20 th inst., after a long, and latterly, severe illness, of Dr. Bence Jones, Secretary to the Royal Institution, the efficiency of which he has done much to promote. Dr. Jones was a distinguished chemist, and among his „contributions to the aavancement of science may be mentioned his Croonian Lectures on Matter and Force, Animal Chemistry in relation to Stomach an 1 